\title{
Às voltas com $O$ homem da bicicleta
}

\author{
Flavia Maria Ferraz Sampaio Corradin ${ }^{1}$
}

RESUMO: $O$ presente artigo tem por objetivo analisar a peça $O$ homem da bicicleta, escrita pelo dramaturgo contemporâneo português Jaime Gralheiro. Escrita e encenada em 1978, foi publicada pela Sociedade Portuguesa de Autores (Lisboa), em 1982. Para tanto, pretendemos buscar as relações intertextuais que a dramatização da narrativa Até amanbã, camaradas, de Manuel Tiago, pseudônimo literário de Álvaro Cunhal, revela, com o intuito de dar-lhe sentido no último quartel do século XX luso.

PALAVRAS-CHAVE: Teatro; Contemporaneidade; História; Salazarismo; Intertextualidade.

\section{Moving around $O$ homem da bicicleta}

ABSTRACT: This paper intends to analyse the play $O$ homem da bicicleta, written by contemporary portuguese playwright Jaime Gralheiro. Written and put on stage in 1978, it was published by Sociedade Portuguesa de Autores (SPA, Lisbon) in 1982. To reach our goal we intend to establish the intertextual relations obtained by the transposition of the novel into a play, in order to make the narrative significant in the last quarter of portuguese 20th century.

KEYWORDS: Theater; Contemporary; History; Salazarism; Intertextuality.

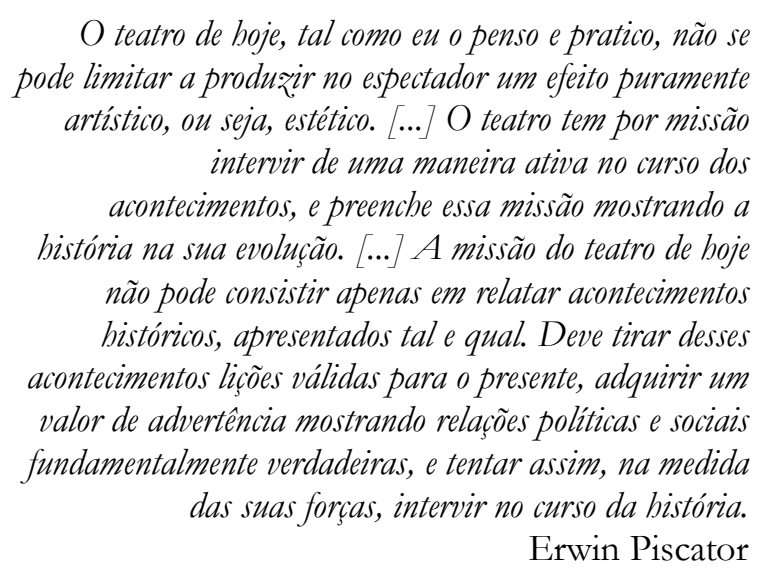

\section{Considerações iniciais}

Antes de enveredar pelo diálogo intertextual travado entre os textos $O$ bomem da bicicleta, de Jaime Gralheiro, e Até amanhã, camaradas, de Manuel Tiago, consideramos necessário observar alguns aspectos que, embora marginais para a análise do texto propriamente dito, parecem substanciais para compreendermos, dentre outros aspectos, a razão que leva um autor contemporâneo português a travar diálogo com um texto que, aparentemente, trata de uma

\footnotetext{
${ }^{1}$ Professora Associada da Universidade de São Paulo.
} 
realidade, digamos, datada da História portuguesa.

O primeiro aspecto relevante incide no fato de não se saber com precisão científica o ano de publicação da narrativa: seria 1949? seria 1974? seria 1975? Segundo Francisco Melo, primeiro editor de Até amanhã, camaradas (Edições Avante!), o volume foi publicado em finais de 1974, portanto depois da Revolução dos Cravos (25 de abril de 1974), que põe fim à ditadura do Estado Novo. Além disso, quando da publicação, na Nota sobre o Autor, lê-se:

O original dactilografado do romance Até amanhã, camaradas foi encontrado, junto de outros originais, num arquivo formado, no decurso dos anos, ao sabor de incidentes e de acidentes na vida agitada daqueles mesmos dos quais o romance dá alguns exemplos típicos.

Desconhece-se quem é o autor. O único exemplar encontrado não tem assinatura. Só, numa pequena folha apensa e agrafada, podia ler-se, em rabisco apressado, o nome Manuel Tiago, pseudônimo de certeza.

Foram consultadas pessoas que poderiam dar eventualmente indicações conduzindo a uma identificação. Sem resultado. $O$ autor fica assim merecendo o título de "homem sem nome", tal como as personagens do seu romance. (TIAGO, 1989, p. 12).

Importa notar, portanto, quem é Manuel Tiago, em cujas mais diferentes fontes se colhem dados bastante superficiais, como observamos nos três excertos escolhidos diante de uma bibliografia bastante extensa, embora repetitiva:

Pseudónimo literário de Álvaro Cunhal, que com ele assinou obras de ficção, designadamente Até Amanbã, Camaradas (1975), Cinco Dias, Cinco Noites (1975) e $A$ Estrela de Seis Pontas (1994, adaptado para cinema por José Fonseca e Costa). A verdadeira identidade de Manuel Tiago só foi confirmada aquando da publicação deste último romance. Durante anos, muito se especulou acerca da autoria das obras. ${ }^{2}$

Com o pseudónimo de Manuel Tiago, [Álvaro Cunhal] assinou vários romances, mantendo em incógnita, até aos anos 90, a sua identidade como romancista, enigma adensado pela "Nota sobre o autor" que precede Até Amanbã, Camaradas, original atribuído a um "homem sem nome, tal como as personagens do seu romance". ${ }^{3}$

Para a maioria dos portugueses, e durante muito tempo, Álvaro Cunhal foi o homem que deu a cara pelo PCP. Só mais tarde se descobriu que o mesmo homem que se empenhava de corpo e alma na política guardava ainda energia para escrever e pintar.

Numa estética fortemente neorrealista, panfletária, maioritariamente seguida por autores comprometidos política e socialmente, Manuel Tiago (pseudónimo literário de Cunhal) foi publicando romances em que a clandestinidade, a passagem pelos calabouços da polícia política, o quotidiano dos militantes comunistas e do proletariado eram temas fortes. A literatura, claro, estava ao serviço da crença política do escritor.

No Dicionário da Literatura Portuguesa, António José Saraiva e Óscar Lopes defendem que o relato ficcionado da experiência de Cunhal é «o mais

\footnotetext{
${ }^{2}$ Disponível em: http://www.wook.pt/authors/detail/id/9877. Acesso em: 03 maio 2011.

${ }^{3}$ Disponível em: http://www.infopedia.pt/\$manuel-tiago. Acesso em: 03 maio 2011.
} 
informativo, o mais exemplar e vivencialmente denso dos romances baseados numa intensa e íntima experiência de organização clandestina».

Só em 1995, já arredado da política activa, o histórico líder comunista revelou o rosto que o pseudónimo Manuel Tiago escondia. Entretanto, já publicara a trilogia formada pelos romances Até Amanhã, Camaradas (recentemente adaptado à televisão por Joaquim Leitão), Cinco Dias, Cinco Noites (levado ao cinema em 1996, por José Fonseca e Costa), A Estrela de Seis Pontas e ainda A Casa de Eulália. Ao morrer, esta madrugada, aos 91 anos, Álvaro Cunhal leva consigo não só o político, mas também o escritor. ${ }^{4}$

O último fragmento aponta mais claramente para a atividade política de Álvaro Cunhal. Tal engajamento, porque está intimamente relacionado com o romance que serve de paradigma para a releitura proposta por Gralheiro, em O homem da bicicleta, ocupará as linhas seguintes.

Álvaro Barreirinhas Cunhal nasce em Coimbra, no dia 10 de novembro de 1913, filho de Avelino Henriques da Costa Cunhal, advogado de profissão, republicano e liberal, e de Mercedes Simões Ferreira Barreirinhas Cunhal, católica fervorosa. O pai retira-o da escola primária porque não queria que o filho "aprendesse com uma professora primária autoritária", conforme relatado em entrevista publicada no Diário Popular, de 10 de maio de 1991. Aos onze anos, muda-se com a família para Lisboa, onde é matriculado no Liceu Camões, para ingressar, depois, na vida acadêmica, ao cursar a Faculdade de Direito da Universidade de Lisboa, iniciando aí sua atividade revolucionária.

Em 1931, com dezessete anos, filia-se ao Partido Comunista Português e integra a Liga dos Amigos da URSS e o Socorro Vermelho Internacional. No ano de 1934 é eleito representante dos estudantes no Senado da Universidade de Lisboa, para no ano seguinte chegar a secretário-geral da Federação das Juventudes Comunistas. Segundo uma biografia publicada em 1954, pelo Secretariado do PCP, Álvaro Cunhal teria entrado na clandestinidade em 1935 e participado do VI Congresso da Internacional Juvenil Comunista em Moscou. Em 1936 é cooptado para o Comitê Central do PCP, que o envia à Espanha, onde vive os primeiros cinco meses da guerra civil. No ano seguinte, é preso pela primeira vez, no Aljube, e posteriormente transferido para Peniche. Um ano depois é libertado, mas por razões políticas é obrigado a cumprir o serviço militar, em dezembro de 1939, na Companhia Disciplinar de Penamacor. Por razões de saúde, Álvaro Cunhal acaba por ser dispensado pela Junta Médica Militar.

Na década de 30, colabora com vários jornais e revistas como a Seara Nova e o O Diabo, e nas publicações clandestinas do PCP, o Avante e O Militante, com vários artigos de intervenção.

Em 1940, mais uma vez é preso, sendo escoltado pela polícia à Faculdade de Direito,

\footnotetext{
${ }^{4}$ Disponível em: http://www.icicom.up.pt/blog/muitaletra/arquivos/008807.html. Acesso em: 03 maio 2011.
} 
onde apresenta a sua tese da licenciatura em Direito, acerca da temática do aborto e da sua despenalização, tema pouco vulgar para a época, ainda mais em se tratando de o país estar sob uma ditadura, cujos valores morais, se é que se pode chamar assim, são bastante retrógados.

A sua tese, apesar do contexto político pouco favorável, é classificada com “dezasseis valores". Do júri fazem parte os professores Paulo Cunha, Cavaleiro Ferreira e Marcello Caetano, figuras destacadas do regime salazarista.

Devido aos seus ideais comunistas e à sua assumida e militante oposição ao Estado Novo, esteve preso, conforme apontado, em 1937, 1940 e depois entre 1949-1960, num total de treze anos, oito dos quais em completo isolamento, tendo sido mantido incomunicável durante catorze meses. O julgamento relativo a essa última prisão ocorre um ano depois, quando Cunhal declara ser "filho adoptivo do proletariado", além de dirigir um forte ataque ao regime salazarista.

Em 3 de janeiro de 1960, Cunhal, juntamente com outros membros destacados do PCP, protagonizam a célebre fuga de Peniche, possível graças a um planejamento muito rigoroso e a uma grande coordenação entre o exterior e o interior da prisão. Em 1962 é enviado pelo PCP para Moscou, depois para Paris. Ocupa o cargo de secretário-geral do Partido Comunista Português, sucedendo a Bento Gonçalves, entre 1961 e 1992, tendo sido substituído por Carlos Carvalhas. Em 1968, Álvaro Cunhal preside à Conferência dos Partidos Comunistas da Europa Ocidental, o que é revelador da influência que já nessa altura detém no movimento comunista internacional. Neste encontro, mostra-se um dos mais firmes partidários da invasão da então Checoslováquia pelos tanques do Pacto de Varsóvia, ocorrida nesse mesmo ano.

Regressa a Portugal cinco dias depois do 25 de abril de 1974. É ministro sem pasta no I, II, III e IV governos provisórios e também deputado à Assembleia da República entre 1975 e 1992. Em 1982, torna-se membro do Conselho de Estado, abandonando estas funções dez anos depois, quando sai da liderança do PCP.

Além das suas funções na direção partidária, é romancista e pintor, escrevendo sob o pseudônimo de Manuel Tiago, o que só revela em 1995.

Nos últimos anos da sua vida sofre de glaucoma, acabando por cegar. Falece em 13 de junho de 2005, em Lisboa, e no seu funeral, ocorrido em 15 de junho, participam, segundo dizem, mais de duzentas e cinquenta mil pessoas. Seu corpo é cremado. Deixa como descendência uma filha, Ana Cunhal, nascida em 25 de dezembro de 1960, fruto da sua relação com Isaura Maria Moreira.

Álvaro Cunhal ficou na memória como um comunista que nunca abdicou do seu ideal. Em momento azado, retomaremos aspectos da atividade política de Cunhal que tenham 
relação direta com o romance Até amanhã, camaradas, relidos na peça $O$ bomem da bicicleta.

\section{Até amanhã, camaradas}

A longa narrativa, composta por dezoito capítulos, todos eles subdivididos em partes, ambienta-se entre os anos de 1943/1944, fazendo explícita referência a alguns sítios. Dentre eles, destacam-se: Vale das Éguas, freguesia portuguesa, do Concelho de Sabugal, Distrito da Guarda, Beira Alta, com 4,03 km² de área e quarenta e oito habitantes (censo de 2001); Aldeia do Mato, Concelho de Abrantes, Distrito de Santarém, divisa com o Concelho de Constança, próximo a Tomar, Ribatejo, com 31,4 km² e quinhentos e sessenta habitantes (censo de 2001); Valeira, embora não se tenha conseguido determinar com precisão onde fica a localidade, parece ser perto de Bragança, Trás-os-Montes; sem falar obviamente de Lisboa. Como podemos perceber, tais localidades não são o que se pode chamar de vizinhas, uma vez que estão espalhadas por grande parte do território português. Se num primeiro momento parece inverossímil que um dos protagonistas, Vaz, percorra distâncias bastante longas com uma bicicleta, sob toda sorte de intempéries, o que, na verdade, traz verossimilhança à proposta são as lutas travadas em torno da ação do Partido Comunista Português, a unir tais espaços. Mais explicitamente, podemos falar do alargamento na atuação dos comitês regionais na incansável batalha, por vezes inglória, para com a ajuda da militância do PCP, transformar a condição de vida de regiões, por vezes bastante distantes dos centros mais desenvolvidos.

Nesse momento, talvez valha a pena, em linhas muito gerais, uma vez que não é objeto deste estudo, fazer um breve histórico do PCP. Obviamente não se quer com isso esgotar as informações em torno da Organização nem, muito menos, tomar partido acerca de questões políticas que envolvem o pensamento comunista.

O Partido Comunista Português caracteriza-se pelo marxismo-lenilista, baseando-se no centralismo democrático, além de considerar-se patriótico e de caráter internacionalista. $\mathrm{O}$ partido é fundado em 1921, como a seção Portuguesa da Internacional Comunista. Legalizado no fim dos anos 1920, o PCP tem um papel fundamental na oposição ao regime ditatorial conduzido, por muitos anos, por António de Oliveira Salazar. Durante as cinco décadas de ditadura, o PCP participa ativamente na oposição ao regime e é o partido (clandestino naquela época) mais organizado e mais forte da oposição. É perseguido constantemente pela polícia política, a PIDE, que obriga os seus membros a viverem clandestinamente, sob a ameaça de serem presos, torturados ou assassinados. Mas a determinação dos seus membros e o apoio financeiro da União Soviética garantem a sua continuidade. Após a Revolução dos Cravos, em 1974, os trinta e seis membros do Comitê Central, em conjunto, tinham já cumprido mais de 
trezentos anos de prisão.

Após o fim da Primeira Guerra Mundial, em 1918, Portugal cai numa grave crise econômica, em parte devido à intervenção militar na guerra. A classe dos trabalhadores responde ao deteriorar do seu nível de vida com uma onda de greves. Com o apoio da União Operária, crescem as movimentações reivindicativas e, no fogo dessas lutas, a classe operária conquista, finalmente, a histórica vitória da jornada de oito horas de trabalho. Em setembro de 1919, o movimento da classe dos trabalhadores funda a Confederação Geral do Trabalho, ou CGT. Contudo, a falta de poder político devido, por sua vez, à falta de uma estratégia política coerente entre os trabalhadores, leva à fundação da Federação Maximalista Portuguesa (FMP), em 1919. O seu principal objetivo é promover ideias revolucionárias e socialistas, e organizar e desenvolver um movimento dos trabalhadores.

Após algum tempo, os membros da FMP sentem a necessidade de uma vanguarda revolucionária entre os trabalhadores portugueses. Depois de várias reuniões em diversas sedes dos sindicatos, e com a ajuda da Comintern, é fundado o Partido Comunista Português, ou PCP, como a seção Portuguesa da Internacional Comunista (Comintern), no dia 6 de março de 1921. Em novembro de 1923, ocorre em Lisboa o primeiro congresso do PCP, com José Carlos Rates na liderança do partido. Cerca de cem membros do partido atendem ao congresso, afirmando a sua solidariedade com o socialismo na União Soviética e a necessidade de políticas semelhantes em Portugal; alerta também para o perigo que um regime fascista traria para o Partido e para o país. Após a Revolução de 28 de maio de 1926, o partido é ilegalizado, sendo forçado a operar em segredo. Por coincidência, a revolução acontece na véspera do segundo congresso, o que leva à sua suspensão. Em 1927, a sede do Partido é fechada. Depois de ser reorganizado em 1929, por Bento António Gonçalves, o PCP adapta-se ao seu novo modo de operações clandestinas, evitando assim uma onda de detenções. O PCP apenas restabelece relações com o movimento comunista e com a União Soviética em 1947, após contatos esporádicos por intermédio dos partidos Comunistas da Espanha e da França. Após a ascensão ao poder do regime ditatorial de Salazar, ou Estado Novo, a repressão ao partido aumenta. Muitos de seus membros são presos, torturados e assassinados, alguns deles são enviados para o campo de concentração do Tarrafal, em Cabo Verde, dentre eles Bento Gonçalves, que acaba por morrer no campo. Esta vasta onda de detenções leva a uma grande reorganização em 194041. O primeiro congresso após estas mudanças ocorre em 1943, e é decidido que o Partido se deveria unir com todos os que querem acabar com a ditadura. Outra decisão importante é a necessidade de aumentar a influência do Partido dentro do exército Português.

O Partido consegue, assim, pela primeira vez, criar uma organização clandestina forte, 
que ajuda significativamente a resistência contra o regime de Salazar. Em 1945, com a queda dos principais regimes fascistas na Segunda Grande Guerra Mundial, Salazar é forçado a simular algumas mudanças democráticas, para manter uma boa imagem no Ocidente. Autoriza a criação de uma resistência democrática, chamada Movimento de Unidade Democrática, ou MUD, inicialmente controlada por uma oposição moderada, mas cedo se torna altamente influenciada pelo PCP. Na direção da sua ala jovem estão alguns comunistas como Octávio Pato, Salgado Zenha, Mário Soares, Júlio Pomar e Mário Sacramento. O MUD é ilegalizado pelo governo em 1948, após várias ondas de supressão. O quarto congresso, realizado em julho de 1946, aponta para um grande movimento popular como única maneira de derrotar o regime, e indica as políticas que o Partido iria levar a cabo para liderar esse mesmo movimento. Esta decisão, juntamente com a consolidação do trabalho clandestino, é a principal conclusão do congresso. Um breve relatório destas medidas é publicado pelo Comitê Central do Partido Comunista da União Soviética. Entretanto, Álvaro Cunhal viaja até a antiga Iuguslávia, com a ajuda de Bento de Jesus Caraça, com o intuito de melhorar as relações com o Bloco Socialista. Em 1948, viaja até à União Soviética para falar com Mikhail Suslov, após as ligações entre o PCP e o Movimento Internacional Comunista terem sido restabelecidas. Quando regressa da União Soviética, Cunhal é preso pela polícia política de Salazar, a PIDE. O quinto congresso, em setembro de 1957, realiza-se no Estoril. O Partido aprova os seus primeiros estatutos e o programa. O congresso toma, pela primeira vez, uma posição oficial em relação ao Colonialismo, defendendo que todas as pessoas têm o direito à autodeterminação, e deixa claro o apoio aos movimentos populares de libertação das colônias portuguesas. Em janeiro de 1960, um grupo de dez membros do PCP consegue fugir da prisão de alta-segurança de Peniche, conforme já apontamos. Várias figuras do topo do partido participam da fuga, dentre elas Álvaro Cunhal, que seria eleito no ano seguinte o primeiro Secretário-geral em dezenove anos. Também dentre os fugitivos está Jaime Serra, que iria organizar secretamente o grupo de Ação Revolucionária Armada ou ARA. O ARA é um grupo armado do PCP, responsável por alguns golpes militares contra o regime ditatorial nos anos 1970. Em 1961 começa a Guerra Colonial em África, primeiro em Angola, depois em Moçambique e Guiné-Bissau. A guerra estende-se por treze anos e é um duro golpe para a sociedade portuguesa, forçando milhares de jovens a deixar o país, tanto para procurar melhores condições de vida na França, Alemanha e Suíça, como para fugir à guerra. O Partido, que esteve envolvido na formação de movimentos de guerrilha nacionalistas, juntamente com a União Soviética, toma imediatamente uma posição de oposição forte à guerra e de apoio aos movimentos anticoloniais. A guerra, criando grande instabilidade na sociedade, ajuda no declínio do regime de Salazar. Em 1962, instala-se a "Crise 
Acadêmica". O regime, temendo a crescente popularidade das ideias democratas no meio estudantil, ilegaliza várias associações e organizações. A maioria dos membros destas organizações é de intelectuais comunistas militantes perseguidos e proibidos de continuar os seus estudos universitários. Os estudantes, com o forte apoio do PCP, respondem com demonstrações que culminam no dia 24 de março em Lisboa. Essa manifestação é brutalmente reprimida pela polícia, acabando com vários estudantes feridos. Segue-se imediatamente uma greve dos estudantes contra o regime. No sexto congresso, em 1965, Álvaro Cunhal, eleito Secretário-geral em 1961, elabora um relatório chamado Rumo à Vitória. As tarefas do Partido na Revolução Democrática e Nacional se tornam um documento de grande influência dentro do movimento democrático. Distribuído largamente entre os membros clandestinos, contém oito objetivos políticos, tais como "o fim dos monopólios na economia", "a necessidade de uma reforma agrária e redistribuição das terras" e "a democratização do acesso à cultura e à educação" - políticas que o Partido considera essenciais para tornar Portugal um país inteiramente democrático. Nove anos mais tarde, no dia 25 de abril de 1974, a Revolução dos Cravos põe fim a quarenta e oito anos de resistência e marca o início de um novo ciclo na vida do Partido.

Este longo parêntese faz-se necessário, uma vez que o grande mote do volume é exatamente o dia a dia do PCP, ou melhor, a organização e ampliação da militância comunista em locais onde a estrutura do Partido é mais frouxa. Assim, a conscientização das massas em questões como reforma agrária, participação do proletariado nas decisões do patrão ou a praça de jorna ${ }^{5}$ são o tema central que move a narrativa de mais de trezentas páginas, conforme já deixa patente Urbano Tavares Rodrigues, na contracapa da edição de 1989 de Até amanhã, camaradas, a qual utilizamos neste estudo:

A humanidade profunda na austeridade de quem entrega a sua vida à causa da libertação de um povo merece todo o fluir da narração, as reacções de muitas das figuras. Se é certo que o campo e os camponeses pobres e explorados, os pinhais de névoa, a desconfiança dos humildes, a bravura dos operários nas suas greves aqui aparecem, o tema central é a vida do Partido, as ligações, as casas de apoio, os contactos e precauções; por fim a prisão, a tortura, a morte. No presente um romance histórico, a diversos títulos: como obra de arte que é; como testemunho de alcance sociológico e político; como exercício moral (não confundir com moralizante, no estrito sentido apologético). Em resumo, um grande livro, inesperado e onde os sentimentos mais fortes e puros do homem encontram a simplicidade e o rigor transparente da expressão.

\footnotetext{
${ }^{5}$ Entre os camponeses de certa região, designa-se por «praça» o ajuntamento dos assalariados rurais em locais certos e dia fixado, com o fim de contratarem trabalho, ou - como usam dizer - tomarem patrão. Soeiro Pereira Gomes. Disponível em: http://voarforadaasa.blogspot.com/2008/12/blog-post.html. Acesso em: 28 abr.2011.
} 


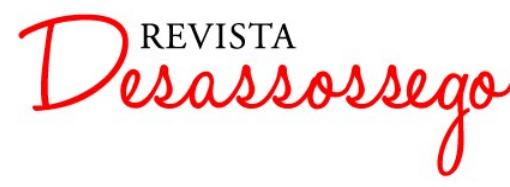

DESASSOSSEGO 20 - parte 2 |JUN/2019 | ISSN 2175-3180

DOI: http://dx.doi.org/10.11606/issn.2175-3180.v11i20p269-285

Se é possível afirmar, a grande personagem da narrativa é o Partido Comunista Português, mais especificamente na década de 40 do século passado, quando há a chamada reorganização, que pretende, em última instância, pôr fim ao regime ditatorial de Salazar.

Além de apontar a difícil vida que levam os membros do Partido em prol de sua organização, vivendo, muitos deles, na clandestinidade, afastados de suas famílias, não podendo inclusive dar notícias aos ou recebê-las dos parentes próximos, cabe ressaltar o importante papel que o Partido exerce nas manifestações e greves nas fábricas. Se não se pode apontar exatamente a qual greve o romance se refere, uma vez que a década de 40 do século passado, notadamente os anos de 1943 e 1944, são marcados por muitas delas, é lícito afirmar que, em linhas gerais, estamos diante da fórmula: partido incita os trabalhadores a fazerem greve em prol de melhores condições de vida, trabalhadores deflagram a paralisação, repressão aos atos grevistas pela GNR (Guarda Nacional Republicana), conforme se pode verificar, por exemplo, nos capítulos VII ou XIII. Em seguida, os cabeças das manifestações são presos, torturados e mesmo mortos pela polícia política portuguesa, a PIDE (Polícia Internacional e de Defesa do Estado), como deixa patente o capítulo XVI.

\section{Até amanhã, camaradas na televisão}

Causa certa estranheza que uma novela cuja temática traga à tona uma das questões mais sombrias da História portuguesa, como é a difícil vida dos membros do PCP, notadamente aqueles que fazem as ligações em zonas ermas do território em plena ditadura salazarista, tornese objeto de uma minissérie de televisão em pleno século XXI.

Meio de comunicação ora acusado de lidar com um mundo cor-de-rosa, ora taxado de marrom exatamente porque explora o desprezível, o chocante, extraindo-lhe apenas o hiperbólico com o intuito de levar à comoção certa parcela da população portuguesa ou de qualquer rincão desse mundo globalizado, a televisão comercial, convenhamos, não dedica atenção à reflexão que está nitidamente presente nas páginas de Até amanhã, camaradas, nos episódios televisivos ou nas cenas de $O$ homem da bicicleta, conforme se pretende apontar em momento azado.

Estamos nos refereindo à minissérie Até amanhã, camaradas, transmitida pela SIC, em seis episódios, nos dias 28 e 29 de janeiro de 2005, “uma das produções mais caras da televisão portuguesa, interpretada por 140 actores e 2400 figurantes" ${ }^{\circ}$, dirigida por Joaquim Leitão, que substitui na direção Luís Filipe Rocha, autor do argumento, que respeita incondicionalmente o

6 Dados disponíveis em: http://www.publico.pt/media/noticia/ate-amanha-camaradas-vai-ser-serie-de-tv1174014. Acesso em: 17 jan. 2013. 


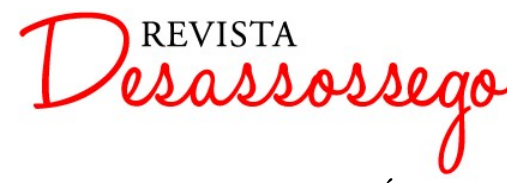

DESASSOSSEGO 20 - parte 2 |JUN/2019 | ISSN 2175-3180

DOI: http://dx.doi.org/10.11606/issn.2175-3180.v11i20p269-285

livro de Manuel Tiago/Álvaro Cunhal, e protagonizada por Gonçalo Waddington, Cândido Ferreira, Leonor Seixas e Paulo Pires.

Em entrevista a Carlos Câmara Lemos e Miguel Madeira, publicada em Público, de 28 de janeiro de 2005, Joaquim Leitão conversa com Álvaro Cunhal duas vezes por telefone e uma pessoalmente com o intuito de dirimir algumas dúvidas que lhe ficaram depois de entrar em contato com o argumento e das muitas leituras que faz da novela propriamente dita. Essas conversas levam-no a optar por se fazer "uma coisa muito sofrida ou então uma coisa que é a ideia que eu tinha - a vida daquelas pessoas era difícil, dura, mas era uma vida entusiasmante". É importante notar que é intenção do realizador deixar de lado qualquer possível referência biográfica na minissérie, como parte da crítica em torno do livro vem apontando ao longo do tempo: "É óbvio que a primeira intuição é ligar o Vaz a Álvaro Cunhal, mas isso é pegar nas coisas muito pela rama...".

Já se apontou algures que o grande mote da novela é a vida de pessoas ligadas ao PCP, suas intenções, desejos, angústias; portanto, a minissérie resgata a ideia de trazer à tona personagens que fundem, dentre outras, tais características, sem estar diante necessariamente de uma individualidade/identidade civil, conforme também refere Joaquim Leitão; "as personagens são inspiradas em combinações de várias pessoas" ${ }^{\prime 8}$. Embora os episódios tenham ido ao ar durante a campanha eleitoral de 2005, o diretor põe em dúvida o fato de a exibição influir favoravelmente nas eleições em prol do PCP, uma vez que não sabe se o público transferiria para a contemporaneidade a militância do passado, no entanto considera que "esta série se for passada daqui a dez anos continuará a funcionar", na medida em que, segundo Francisco Melo, militante do PCP e primeiro editor da novela, estamos diante de:

uma nova obra de arte que não trai, muito pelo contrário, as características essenciais daquela que the deu origem. E isto aplica-se à reconstituição quer política quer humana dos personagens desta gesta histórica dos comunistas portugueses de meados dos anos 40 do século XIX?.

De acordo com o que está estampado no início do Episódio 1, a minissérie ambientase em 1944.

\section{Às voltas com $O$ homem da bicicleta, de Jaime Gralheiro}

Peça em três atos com dezesseis, vinte e uma e vinte cenas respectivamente, escrita em 1978, segundo informação estampada na contracapa, e publicada em 1982 pela Sociedade

\footnotetext{
${ }^{7}$ Público, 28 de janeiro de 2005.

${ }^{8}$ Id. Ibid.

${ }^{9}$ Id. Ibid.
} 
Portuguesa de Autores, "é uma dramatização do romance de Manuel Tiago Até amanhã, camaradas, que evoca a resistência clandestina ao fascismo e foi levada à cena pelo Grupo [Cénico] dirigido pelo autor, em S. Pedro do Sul em 1978”.

Estamos diante de um texto que dialoga intertextualmente com a novela que lhe serve de paradigma, exercitando aquilo que se pode classificar como paráfrase resumitiva, "uma vez que a narrativa ou os diálogos precisam ser encurtados, para que se realize a encenação" (CORRADIN, 1998, p.68). A novela ocupa trezentas e trinta e quatro páginas, na edição de 1989, estampando mancha de página grande, que são retomadas em cento e sessenta e cinco páginas numa edição de bolso da peça, o que deixa clara a necessidade de reduzir o texto. $\mathrm{O}$ dramaturgo suprime dezenas de episódios que estão na novela, com o objetivo de viabilizar a sua dramatização, deixando de lado, as mais das vezes, páginas que tratam da caracterização de personagem, mantendo apenas o que é fundamental para sua empreitada, ou seja, o dia a dia dos membros do PCP e aquilo que concorre para sua militância. O mecanismo intertextual eleito por Gralheiro é a paráfrase resumitiva, na medida em que o intertexto revela bastante semelhança com o paradigma. Tal procedimento obedece a três princípios:

a) rubrica e/ou personagem resume(m) o narrador

A título de exemplo, observa-se: todas as cinco primeiras partes da novela são suprimidas e resumidas na rubrica inicial da cena I, conforme atesta a citação,

(A ação passa-se na década de 1945 a 1955. Inicia-se com um homem pedalando, algures, sobre uma bicicleta. Noite de temporal. Noutro local da ação, a mulher de Manuel Rato anda na lida caseira. O Homem da bicicleta chega. Bate à porta. Vem ensopado, cheio de lama e com aspecto extenuado. A Mulher vai atender). (GRALHEIRO,1978, p.7),

enquanto as partes seis a onze são resumidas nas cenas I e II do primeiro ato. A última cena desse primeiro ato é exemplo de personagem que resume a fala do narrador. Isabel, filha de Manuel Rato, antes de ser morta pelo Tenente da GNR, explicita a insatisfação dos camponeses da região e a mobilização por melhores condições de vida, no diálogo que trava com seu assassino.

b) personagem da peça resume fala da mesma personagem da novela

Chamamos atenção, por exemplo, para a parte sete do capítulo X, que é resumida na cena XI do segundo ato da peça. Protagonizada por Paulo e Maria, a cena trata da tristeza da moça, que se mostra uma verdadeira militante, embora faqueje aqui e ali, ao sentir saudades da vida familiar. Para ilustrar a questão, elegemos a seguinte fala de Paulo, que resume parafrasicamente o que está diluído na voz do narrador: 
Sabes? na origem de tudo quanto de belo se fez na história da humanidade, sempre, sempre, esteve o sonho. Todos sonhamos, amiga, todos. Sonhamos com um mundo melhor, onde os homens não vivam da dor de outros homens, onde não se matem crianças com metralhadora e à fome, onde o ar se respire em liberdade. Mentiríamos aos outros, e a nós próprios, se negássemos que sonhamos também com a felicidade pessoal, que ansiamos ardentemente o amor, filhos, e que o inimigo os não mate, que ansiamos por tranquilidade, e um pouco de conforto... Os militantes, amiga, dão tudo, mas não devem renunciar a nada. Se matássemos o sonho, matávamo-nos a nós próprios. (GRALHEIRO,1978, p. 83)

c) personagem da peça resume fala de outra personagem da novela

Dentre outros possíveis exemplos, destacamos aquele que trata do momento em que Afonso passa à clandestinidade. Ele é instruído a estar em determinado local, numa certa hora, e deve utilizar como meio de transporte o comboio, depois uma camioneta. Ele desobedece às ordens e pega "uma boleia numa camioneta de carga de um amigo" (TIAGO, 1989, p. 74), fazendo o restante do percurso a pé. A recriminação na novela vem pela boca do camarada Fialho, que dirigiria e controlaria Afonso. Na peça, essa personagem não existe, porém sua função é exercida por Vaz, que lhe explica "o camarada que estava encarregado desta tarefa teve de ir cumprir outra. Tive de o substituir." (GRALHEIRO, 1978, p.73), porém a recriminação é parafrásica nos dois textos: na novela "-Começas mal, - camarada - repetiu Fialho, secamente." (TIAGO, 1989, p. 142), enquanto na peça, Vaz afirma: "Começas mal, amigo, muito mal! Quando o Partido nos dá determinadas diretrizes são para se cumprirem.” (GRALHEIRO, 1978, p. 74)

O excerto acima também exemplifica um outro mecanismo de adaptação da novela para o espaço do teatro. Trata-se da supressão de personagem, que, obviamente, tem a ver com a economia necessária ao espaço cênico.

O terceiro ato revela exemplos de acréscimo de situação, uma vez que a cena $V$, em que contracenam dois Pides, o Presidente da Câmara e o Diretor da Cicol, fábrica fictícia onde se instala o movimento grevista, instigado pelo Partido, não existe na novela. A ideia da delação estimulada pelos Pides que querem encontrar os cabeças da greve e necessitam da ajuda do Diretor da fábrica e do Presidente da Câmara, com certeza, encontra respaldo em procedimentos típicos da polícia política portuguesa que, embora satirizada na fala do segundo Pide: “E vá lá agora a gente descobrir, entre milhares, um com sardas e uma névoa na vista!... Porca de vida!...” (GRALHEIRO, 1978, p. 124), promove uma verdadeira caça às bruxas, muitas vezes prendendo, torturando e mesmo matando pessoas que não tinham relação direta com o fato em questão. Também a cena VII, em que "Na praça de jornal. Vários trabalhadores aguardam. Um Agrário, acompanbado por um desconhecido (Pide) passeia pela praça e conversa com um e 
outro" (GRALHEIRO, 1978, p. 126), em busca de encontrar o mandante da greve, acaba por reconhecer no Sagarra aquele "com sardas e uma névoa na vista" (GRALHEIRO, 1978, p. 129).

Algumas cenas da peça são alteradas frente ao paradigma, apresentando maior ou menor grau de refração em relação ao modelo, conforme se pode perceber no final da cena XIV, nas cenas XVII e XIX.

Na primeira cena apontada, Rosa confessa a Vaz que tem uma filha, conforme também é relatado na parte três do capítulo XV da novela (TIAGO, 1989, p. 267-269). A diferença está apenas no fato de que na peça Rosa aponta como pai da criança o dono da fábrica onde trabalhava antes de entrar para o Partido, ressaltando seu ódio à classe burguesa, segundo aparece na narrativa.

A cena XVII relê o final do capítulo XV, que trata da morte de Ramos. Na novela, ele é recebido na casa dos Pereiras por uma senhora que afirma que eles não estão e dá a entender que há PIDES no interior da residência; quando Ramos percebe, começa a mastigar as folhas de uma agenda que portava. Releva notar que é imediatamente antes do relatado que Ramos profere a frase que dá título à novela: Até amanhãa, camaradas, ao despedir-se de um casal de velhos que lhe dera abrigo. Na peça, é um PIDE que atende à porta, insistindo demasiadamente para que ele entre, o que denota algo estranho, fazendo com que ele mastigue as páginas da agenda. Em ambos, Ramos é baleado na tentativa de fuga.

Na cena XX, Pereira delata o camarada Vaz, depois de ser barbaramente torturado, e é execrado pela mulher, Conceição, que aguenta tudo, mas não confirma nada que o marido diz, enquanto, na novela, Pereira denuncia vários camaradas e depois volta atrás, quando é informado da morte de Ramos. Conceição não trai os militantes do PCP, conforme também está no paradigma.

O maior grau de refração entre a novela e a peça está nas páginas finais. Na narrativa, Vaz, com a saúde bastante debilitada, "caminharia sempre e sempre com uma energia feroz, enquanto (...) tivesse um sopro de vida" (TIAGO, 1989, p. 330). Maria passa a trabalhar na organização das mulheres da indústria têxtil, a célula do Partido na região, prospera e novos camaradas estão engajados na militância.

Na peça, no entanto, temos final diferente, uma vez que Vaz e Rosa desaparecem, Maria, Paulo, Manuel Rato, Lisete e Afonso são os únicos capazes de reatar as ligações do Partido na região, Afonso é perdoado das graves faltas, apontadas por Vaz na cena IX do $3^{\circ}$ ato:

AFONSO: Tive saudades da minha mãe! 


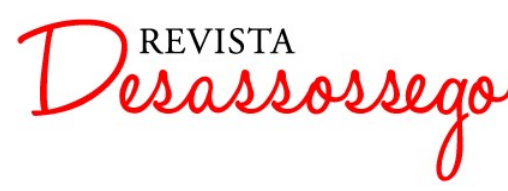

DESASSOSSEGO 20 - parte 2 |JUN/2019 | ISSN 2175-3180

DOI: http://dx.doi.org/10.11606/issn.2175-3180.v11i20p269-285

VAZ: Tiveste saudades! (...) Tu não vês que companheiros nossos estão a ser presos; que andam em cima de nós como cães, tu não vês que estás a pôr em risco a liberdade de centenas de camaradas; que o teu "cansaço" que não é "cansaço", que as tuas "saudades" que não são saudades, mas sim falta de espírito revolucionário, podem deitar por terra o trabalho clandestino de todos aqueles que, durante anos, dia a dia, têm vindo a renunciar a tudo para transformar este país de vergonha numa pátria de justiça e liberdade, onde nunca mais seja preciso andar a fazer de noite isto que deve ser feito à luz do dia e com a participação de todos!? Não deste conta?! O que tens feito são verdadeiros crimes contra o Partido. E se não és um vulgar provocador (que eu continuo a julgar que não és) estás a agir como um autêntico garoto! Não sei o que é o Partido. Não sei o que é que o Partido vai decidir a teu respeito. Se fosse um verdadeiro comunista, que a lição te aproveite. Se não te aproveitar é um homem atirado ao charco!... Boa noite!....(Afasta-se e deixa Afonso sozinho, Afonso chora). - (GRALHEIRO, 1978, p. 134),

sendo reintegrado ao Partido depois de, estando fora da militância, perceber e apontar que Vitor é o verdadeiro traidor e não Cesário, que morre nas mãos da PIDE. Afonso assume, senão as funções de Vaz, papel preponderante nas ligações do Partido, tomando a antiga bicicleta do camarada desaparecido, e segue cumprindo as tarefas a ele designadas, dizendo Até amanhã, camaradas. Vale ressaltar a rubrica final da peça:

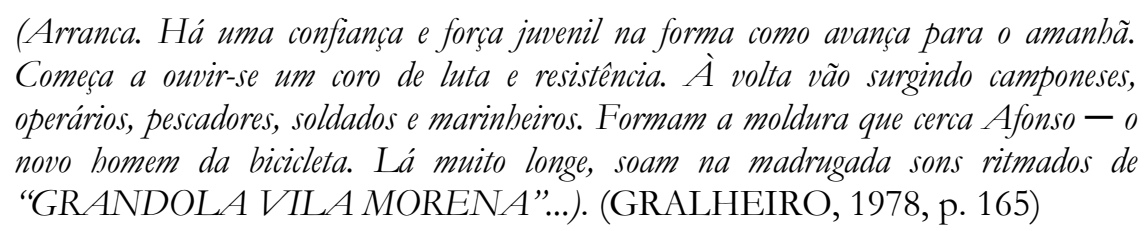

\section{Considerações finais}

Dois signos chamam especial atenção. O primeiro refere-se exatamente ao motivo por que Afonso falha nas suas tarefas e que o leva a ser expulso dos quadros do Partido: a saudade. Parece que Jaime Gralheiro explicita de maneira contundente a situação de atraso em que se encontra Portugal no período em que a peça é ambientada, isto é, a década de 40 do século passado, estendendo tal inércia a todo o período salazarista. Ao examinar as questões que envolvem a palavra "saudade", talvez se encontre a grande refração que a peça promove em relação ao paradigma.

Eduardo Lourenço, em Mitologia da saudade (1999), elenca a "história da saudade", iniciando sua perquirição, conforme já apontamos, com o escrito de D. Duarte, intitulado Leal conselheiro, que contém, segundo o ensaísta, "a primeira meditação conhecida sobre a saudade", embora tal sentimento não seja o centro de sua atenção, o rei escritor aponta que o termo "não tem equivalente nem em latim nem outra linguagem, próprio como nenhum outro para exprimir a estranheza e a sutileza de um sentimento de tal complexidade. [Portanto,] Portugal torna-se miticamente a terra da saudade" (LOURENÇO, 1999, p. 22-23). Não se quer aqui adentrar os meandros de tal discussão, mas apenas trazer à tona elementos capazes de detectar 
a mundividência expressa pelo paradigma e pelo intertexto em relação a tal questão, que, como já referido, parece estar na gênese da refração do segundo em relação ao primeiro. Assim, saudade caracterizar-se-ia como uma "espécie de perturbação deliciosa que decorre da ausência de um bem e não da negação ou recusa desse bem” (LOURENÇO, 1999, p. 23), tendo, segundo o Leal conselheiro, mais a ver "com a tristeza e o desgosto que com a felicidade. Sentimos saudade, escreve D. Duarte, pela ausência de um ser ou de um lugar amado” (LOURENÇO, 1999, p. 27), portanto "a saudade puxa para o passado, que lhe está no cerne. A saudade traduz a sedução desse passado" (LOURENÇO, 1999, p. 28). Pode-se inferir ainda que, segundo o ensaísta, "saudade subentende, naturalmente, memória" que se constituiria na "autonegação do presente" (LOURENÇO, 1999, p. 32).

Embora já haja elementos suficientes para se pensar a refração promovida pela peça de Gralheiro frente ao modelo tiago/cunhaliano, talvez caiba tratar da distinção entre saudade e nostalgia, em cuja gênese está a ideia de sofrimento por um bem perdido, mostrando-se, portanto, "como um sentimento essencialmente negativo, espécie de luto que o tempo desvanece sem o deixar esquecer” (LOURENÇO, 1999, p. 33), enquanto que, para Teixeira de Pascoaes, o maior nome a refletir em torno da saudade, esta "subtrai a nostalgia ao sentimento da pura perda ou ausência, confiando-lhe a missão de transmudar a perda em vitória ou sonho" (LOURENÇO, 1999, p. 33), apresentando-se, desse modo, como algo positivo.

Evidencia-se que Gralheiro parte da ideia de saudade, no excerto referido acima, sob uma óptica bastante negativa. É a saudade que Afonso sente da família que o leva a cometer uma série de "crimes contra o Partido", é a saudade presente nos pequenos atos de Afonso que metaforicamente levam Portugal a um estado de inércia, atestada e incentivada pelo salazarismo que não permite abandonar o PASSADO heroico, imerso na memória da PÁTRIA perdida e alçar voo para um país que deseja construir um futuro a partir da ideologia do PC. É assim que se pode também compreender tanto a fala final de Afonso como a rubrica que dá fim à peça. Estamos diante da possibilidade de mudança proposta pelo comunismo, que crê que o homem pode modificar-se e agir em prol da coletividade. É assim que Afonso toma a bicicleta de Vaz e sai em busca da construção de um país repleto de homens capazes de agir em nome da construção de um novo mundo. Não se pode esquecer de que a bicicleta que compõe o título da releitura gralheiriana é a metáfora da possibilidade de mudança, conforme corrobora o verbete que a conceitua no Dicionário de símbolos, de Jean Chevalier e Alain Gheerbrant (1982, p. 131-132):

a) trata-se de um meio de transporte movido pela pessoa que dele se utiliza, ao contrário dos outros veículos que são movidos por força alheia. O esforço 
individual e pessoal afirma-se, com a exclusão de toda e qualquer outra energia, a fim de determinar o movimento para a frente;

b) o equilíbrio é assegurado somente pelo movimento para a frente, exatamente como na evolução da vida exterior ou interior;

c) só uma pessoa de cada vez pode montar na bicicleta. Essa pessoa faz o papel de cavaleiro único....

Como o veículo simboliza a evolução em marcha, o sonhador monta no seu inconsciente e vai adiante por seus próprios meios, em vez de meter os pés pelas mãos (...) - i. e., descontrolar-se ou confundir-se por inércia, neurose e infantilismo. Pode contar consigo mesmo e assumir sua independência. Assume a personalidade que lhe é própria, não estando subordinado a ninguém para ir onde lhe aprouver.

Nos sonhos, raramente a bicicleta indica uma solidão psicológica ou real, por excesso de introversão, de egocentrismo, de individualismo, que impeça a integração social: ela corresponde a uma necessidade normal de autonomia.

Parece evidente que a grande refração promovida por Gralheiro frente ao paradigma está nas sugestões que envolvem a bicicleta, que, embora desempenhe papel marcante, seja na novela, seja na minissérie, torna-se a verdadeira protagonista da peça, uma vez que, movida por Afonso, determina "o movimento para frente" buscado pelos militantes comunistas para Portugal. O passado heroico, glorioso, saudoso e, por que não nostálgico, de Portugal deve ceder lugar à evolução equilibrada de vidas exteriores e interiores, verdadeiros "cavaleiros únicos" na divulgação das novas ideias, simbolizadas pela "evolução em marcha”, promovida pelos sonhadores por um mundo melhor, mais equânime e justo que não se cansam de "ir adiante" na incessante busca por retirar a sociedade portuguesa da inércia que a conduz à imobilidade talvez desde a derrocada de Alcácer Quibir.

Ao fim e ao cabo, Afonso e a bicicleta avançam em direção à "integração social" que leva à "autonomia” de cada um em prol do todo português, iniciada pela Grândola Vila Morena, entoada na madrugada do 25 de abril de 1974, e retomada na reconstrução diuturna de uma nação que, embora radicada no passado, vislumbra um futuro, sob a égide impulsionadora do Até amanhã, camaradas. Se as primeiras eleições democráticas ocorridas em 25 de abril de 1976 ainda não puderam concretizar o ideário proposto pelo comunismo, uma vez que o poder é assumido pelos socialistas, liderados por Mário Soares, a possibilidade de mudança se instaura, projetando para o futuro a concretização de uma nação que é sempre passado.

Ainda se espera, no entanto, o pessoano falta "cumprir-se Portugal", uma vez que a economia do país vem sendo tutelada pelo Fundo Monetário Internacional (FMI), que monitora Portugal entre 1977-1978, época em que a peça é escrita e entre 1983-1985, pouco depois da publicação da peça. Na contemporaneidade, com a crise europeia, instaurada a partir de 2008, toda a ação de reestruturação econômica de Portugal está a cargo da troika, triunvirato formado pelo Fundo Monetário Internacional (FMI), pela Comissão Europeia (CE) e pelo 
Banco Central Europeu (BCE). É a troika que irá avaliar as contas reais de Portugal para definir as necessidades de financiamento do país.

Se o futuro português está em outras mãos, bem calharia perguntar "Até [que] amanhã, camaradas?”, já que a situação atual do país é alvo de toda sorte de piada, ideada pelos próprios portugueses e não por brasileiros como sói acontecer. Atentemos, por exemplo, para o jogo de tabuleiro Vem ai a troika!, lançado no final de novembro de 2012, uma das prendas mais vendidas no último Natal. O objetivo do jogo é criar uma teia de influências, vencer as eleições e colocar o máximo de dinheiro possível em paraísos fiscais. A “ação”, segundo Pedro Santos, um dos idealizadores do jogo, passa-se num país chamado Portugalândia e cada jogador representa um "obscuro grupo de interesses que através da manipulação política, social e económica tenta ganhar poder, votos e dinheiro. Qualquer semelhança com a realidade é pura coincidência", ironiza Santos. ${ }^{10}$

\section{Referências:}

CHEVALIER, Jean; GHEERBRANT, Alain. Dicionário dos símbolos. Lisboa: Teorema, 1982. CORRADIN, Flávia Maria Sampaio. Antonio José da Silva, o Judeu. Textos versus (cont)textos. Estudos de Literatura Portuguesa. Org. Francisco Maciel da Silveira. Cotia: Ibis, 1998.

D. DUARTE. Leal Conselheiro. Lisboa: Atlântica, 1965.

GRALHEIRO, Jaime. O bomem da bicicleta. Lisboa: Repertório da sociedade portuguesa de autores, 1982.

LOURENÇO, Eduardo. Portugal como destino- Mitologia da Saudade. Lisboa: Gradiva, 1999.

Público. 28 jan. 2005; 30 nov. 2012.

TIAGO, Manuel (pseudónimo de Álvaro Cunhal). Até amanhã, camaradas. Lisboa: Ediçõesl Avante!, 1989.

http://voarforadaasa.blogspot.com/2008/12/blog-post.html. Acesso em: 28 abr.2011. http://voarforadaasa.blogspot.com/2008/12/blog-post.html. Acesso em: 28 abr.2011.

http://www.wook.pt/authors/detail/id/9877. Acesso em: 03 maio 2011.

http://www.infopedia.pt/\$manuel-tiago. Acesso em: 03 maio 2011.

http://www.icicom.up.pt/blog/muitaletra/arquivos/008807.html. Acesso em: 03 maio 2011. http://www.publico.pt/media/noticia/ate-amanha-camaradas-vai-ser-serie-de-tv-1174014. Acesso em: 17 jan. 2013. http://voarforadaasa.blogspot.com/2008/12/blog-post.html. Acesso em: 28 abr.2011.

10 Público, 30 nov. 2012. 